\title{
Training in the Digitalization of Education: Advanced Learning Technologies and Design Thinking Methodology
}

\author{
Guzaliia Fazylzianova \\ dept. Engineering graphics and design \\ National Research University of Electronic Technology \\ Moscow, Zelenograd, Russia \\ fgi1971@gmail.com
}

\author{
Vitalii Balalov \\ Administration \\ GBU "Mosstroyinform" \\ Moscow, Russia \\ vbalalov@mail.ru
}

\begin{abstract}
This study analyzes world practices in the formation of creative thinking in the education system: from the development of educational programs to the education management system as a whole. It also provides examples of the implementation of this methodology in well-known business companies that implement it in their corporate training programs. Particular attention is paid to advanced learning technologies aimed at technologically supported methods for developing thinking skills (creative thinking, design thinking, decision making, problematic learning, etc.), which, regardless of discipline, are crucial for the success of students - future specialists of the 21st century. The process of parallel formation of creative abilities and digital competencies of teachers in continuing education programs is also possible with the use of design thinking tools. Only such an approach can ensure the training of qualified personnel in demand in the sectors of the digital economy.
\end{abstract}

Keywords: creative thinking, design thinking, digital economy, advanced learning technologies, training

\section{INTRODUCTION}

In the report of the World Economic Forum, the influence of the fourth industrial revolution on the labor market is manifested in the obsolescence of some skills and the growing need for others [1].

A digital economy is unthinkable without qualified personnel and quality education. Personnel and education are one of the key institutions within which conditions are created for the development of the digital economy. Personnel and education are among the basic areas of the digital economy.

The main objectives of the area related to personnel and education are [1]: creating key conditions for training personnel in the digital economy; improving the education system, which should provide the digital economy with competent personnel; labor market, which should be based on the requirements of the digital economy; creation of a motivation system for the development of the necessary competencies and the participation of personnel in the development of the digital economy in Russia.

Both industrial and social spheres are subject to digital transformation, including, of course, education.

Workers in the digital economy should be able to create and process complex information, think systemically and critically, make decisions on a multi-criteria basis, understand the essence of the ongoing processes of a multidisciplinary nature, be adaptive and flexible to new information, be creative, be able to identify and solve problems of the digital world.

Digital skills such as technology design and programming, as well as system analysis and evaluation, are on the rise. But the need for "human" skills, such as creativity, originality and initiative, critical thinking, analysis, complex problem solving, generating ideas, emotional intelligence, is also growing, because they are not expected to be automated in the near future.

Under these conditions, creativity of thinking becomes the main skill in training personnel for any field. Design thinking as a technology for the formation of creative thinking is aimed at human-oriented services and products that are technologically available and economically effective.

In an interview, Pasi Silander, a digital leader in the city of Helsinki and an experienced specialist in the field of digital educational technologies, comments on their introduction in Finnish schools as a means of mastering the skills of the 21st century in the context of introducing advanced learning technologies [2]: "In the modern education system, we must promote the development of future competencies, the so-called 21 st century skills, that is, critical thinking, teamwork, creativity and the skills to acquire new knowledge. It is precisely these communicative skills that are needed, while purely technical skills (for example, memorizing facts, counting) will be taken over in some future by machines ... The process of traditional contact teaching was created mainly on the basis of the teacher's activity and the teaching process while in the process of digital education, the starting point is the learning process of the student himself."

\section{LITERATURE REVIEW AND RESEARCH METHODS}

Over the past 50 years, the "consumption paradigm" has been replaced by a "use paradigm", and companies, in turn, are faced with the fact that all marketing tools used previously are no longer relevant. Then the companies thought about how to work with the "new consumer". The development of design thinking began at Stanford University, founded by David Kelly. The methodology of design thinking implies solving problems with a focus primarily on consumers, has a creative component and borrows the process of designers. David Kelly identified 
According to Plattner, having met with design thinking, several basic principles of design thinking: generation of ideas, a team with various professional experience, maximum empathy towards consumers and rapid prototyping using improvised means [3]. The main difference between design thinking and other design methods is that specialists work in conditions of uncertainty, which helps to take into account all points of view when creating new products and services. Design thinking turned out to be another way of thinking, focused on studying the outside world in terms of identifying the difference between user expectation and user reality in the process of using the finished product. Design thinking uses a combination of divergent and convergent thinking at its various stages, which is also a fundamental difference from other methods. The approach turned out to be ingenious and successfully exists in the marketing of modern companies for about 30 years.

Today, design thinking is actively used in the innovative activities of companies, the approach allows us to identify the hidden needs of potential customers, to understand the person, his motives and values. It is this feature of design thinking that allows the team to focus its attention on the end user and, in the process of innovation, to create an already knowingly valuable proposal [4]. Sberbank, the leading commercial bank in the Russian market, widely uses the method of design thinking, in particular to create innovative products, and all middle and senior managers regularly undergo training at Corporate University in this area.

As practice shows, companies using design thinking are more successful in the market and are more likely to gain a foothold in consumers' memory than organizations less developed in this regard. Large companies, such as Boeing, 3M, SAP, Mail.ru, Group, Procter \& Gamble, Deutsche Bank, often use design thinking in their activities [5].

There are many striking examples of the application of design thinking, showing how it works in practice today. In 2012, PepsiCo realized that design thinking is a leading innovation that ensures that the product meets user expectations and that this leads to a rethinking of the entire range of the company. Especially for women, the shape of the package has changed: the chips are now neatly placed in a plastic tray, the packages are made small so that one serving can be eaten at a time. To test the effectiveness of this approach, PepsiCo conducted a series of tests in the Chinese and Japanese markets. Another example is the Airbnb service, which was created specifically by designers. Each project team at Airbnb includes a manager whose primary goal is to represent the customer's image. Barclays mobile banking has a loyalty level of +62 , largely thanks to the bank's mobile application and the transfer application, which were created in the process of design thinking. Banks have become more creative in providing their products and services. We would also like to note the Wonderfull Design Thinking Laboratory created in Russia, which has been successfully operating since 2016, working both with companies and people who are simply interested in this area.

The Dean of the Rotman School of Management at the University of Toronto, Roger Martin, analyzed the need for changes in the Master of Business Administration (MBA) programs: students need to think more broadly about their thinking design, develop a deeper understanding of the users, and recognize the value of the contributions of others [6]. people experience a steady change in their thinking and how they act and think [7].

The experience of implementing design thinking of a German corporation, one of the leaders in the market of IT solutions, SAP, is known. David Kelly, founder of IDEO, created d.school (Stanford University) in 2004 with Hasso Plattner, co-founder of SAP, in 2004. How does SAP, one of the largest IT corporations, use design thinking in its work? In the areas of IT development, as well as to improve communication within the company and interaction with partners and clients using design thinking, they are actively solving [8]: strategic tasks (which new markets to enter with their decisions, how to make people happier, how can we help equip Russia); internal tasks (how to improve the interaction between the sales department and the contract department, lawyers); creating new products and improving existing ones (how to make a user-friendly interface, what are the hidden needs of the user that could be solved by technologies (for example, developing a mobile application); interaction with customers (how to make a presentation, presentation, demo unforgettable for listeners).

Design thinking methods are actively used in service design and software development. This approach is used by such well-known companies as Apple, Virgin, Toyota, as well as almost all startups to develop their product in large and small accelerators around the world.

Ken Robinson proposes to include forms of training that encourage youth to actively participate in solving global economic and environmental problems and stimulate them to types of economic activity that contribute to the sustainable development and renewal of the planet's natural resources, instead of those that deplete and plunder its bowels [9].

David Kelly in his book "Creative Confidence" [3] says that design thinking is based on the natural (and developed) human ability to be intuitive, find patterns and come up with ideas that are not only emotionally attractive, but also functional, which is why design thinking can be a fairly effective means of developing creative potential and the ability to think outside the box for students of both middle and senior management.

Gusakov's study provides examples of the use of design thinking in various areas of society [6]. In work on social projects, while creating services for city residents. As a Russian example, we can cite new navigation systems in the Moscow metro, in the Tsaritsyno park. Navigation has become clearer and more convenient. Signs appeared right under the feet of passengers in the subway. It is known that a person walks with his head slightly tilted forward. The UK has approved a standard for the development of digital services. All public digital services must comply with it. The standard provides for the need to perform iterative processes for studying the needs and experience of the user, developing a prototype of the service, and testing it. The Australian Taxation Office, which is responsible for administering tax and pension laws in the country, is a pioneer in the application of design thinking methods in its administrative work. The management employs more than 22 thousand employees. All taxpayers - individuals and legal entities interact with this state organization.

Authors of publications on topics of design thinking describe the possibilities of applying this approach in various 
areas of management - in creating new business models and developing an innovative company strategy, to enhance the creative potential of employees, for business analysis, in small business.

The article [8] analyzes the experience of the Financial University in implementing an online entrepreneurship course for students and undergraduates in the context of training for the new digital economy, when researchers with the gift of foresight, capable of adaptation and constantly working on insight and insight are needed. The main content of the course was the answers to the questions: How can researchers make Generation Z? How to develop their creativity, creative thinking?

A new form of training was developed based on the inclusion in each of the classes of the techniques of thinking design popular today among the IT solution developers [10].

It was proposed to consider design techniques of thinking precisely from the point of view of their applicability to the initial stages of a startup's life cycle. The formation of Internet start-ups is considered according to the main periods of development: from choosing an idea, where the emphasis is placed on the direction of its development to the request of the buyer, through its confirmation in Customer Discovery Methodology and the creation of a Minimal Viable Product to testing and first sales .

In design thinking, much attention is paid to the iteration of the process and to turning around - discarding ideas that are not justified in the prototype: construction and modeling allow you to better think out and determine the correct idea: prototype - think with your hands.

The problem of creating startups is the inability to generate ideas and manage the process of their creation.

Thinking design techniques are aimed at developing a non-standard solution by a team of participants in the face of uncertainty, where classical management techniques are not applicable. The format for creating and implementing a startup exists precisely in conditions of increased risk and uncertainty.

Brainstorming in teams to gain joint game experience and practical teamwork and team discussion skills is undoubtedly useful.

Design thinking allows you to engage a wide range of opinions from people with different views, different points of view, to identify hidden risks and problems or unconscious needs.

The article [8] presents the experience of using new experimental methods of education for the development of creative abilities, research skills and building communications in the preparation of IT students. The features of conducting sessions by the method of design thinking in high school are highlighted. The directions of using new educational techniques for inclusion in the training course for technological entrepreneurship are considered. The analysis of design thinking sessions is presented.

\section{RESULTS}

Gusakov's study [6] emphasizes that at present the study of design thinking has been included in the programs of many leading universities and business schools in the world.
As a rule, classes are held in the form of optional courses for students (d.school at Stanford University) or are part of a longer program (Product Development Project course at Aalto University, Helsinki). Both short-term and longer-term immersion programs in design thinking are offered for professionals and managers in various fields of activity. An example of a short-term program is the three-day "Executive Education program" at Stanford University's d.school. Training in the Innovation and Design Thinking program at the Massachusetts Institute of Technology Sloan School of Management takes two months. In Europe, the largest center for design thinking is the HPI D-School, which implements programs in various formats - for students, teachers and professionals.

In Russia, design training in thinking is mainly provided by private educational institutions, such as the British Higher School of Design. Short-term intensives are conducted by companies providing consulting services in the field of service design. In higher education in Russia, design thinking occurs in the form of an optional course or as a methodology in the disciplines related to innovation: in the master's program of the Faculty of Economics of Moscow State University, at Moscow State Technical University. N.E. Bauman. At the Russian Academy of National Economy and Public Administration, design thinking is used in the work of student teams on projects of potential employers.

The author gives examples of teaching design thinking skills within the framework of teaching various disciplines in undergraduate and continuing education programs, as well as in organizing innovative projects in which both schoolchildren, students, and professionals, and leaders from various fields of activity participated. Within the framework of undergraduate programs, design thinking was used at the sociology faculty of the Northern Arctic Federal University, at the faculty of large city management at Moscow International University, at the economics faculty of the Peoples' Friendship University of Russia. Design thinking was embedded in the advanced training program for project management of employees of state authorities, local authorities and heads of municipal organizations in the city of Naryan-Mar (Nenets Autonomous Okrug). As part of the educational project of the Moscow City Department of Education "University Saturdays", design thinking was also used.

In the framework of the Project 5-100 "Enhancing the Competitiveness of the Leading Russian Universities Among the World's Leading Scientific and Educational Centers", the joint educational development program "Design Thinking in Education" was developed and implemented at the Peoples' Friendship University of Russia together with Tomsk State University. The program managers were representatives of partner universities G. Fazylzyanova G. Mozhaeva. The program was implemented as part of continuing education for current teachers in Moscow and Tomsk, as well as in an international format for teachers in Weinan and Xi'an (China). A feature of the program is that the first module of the program was implemented online, and the second module in the format of strategic sessions. The final exam of students was held in the format of web-presentation of team projects "Digital lessons at school".

At Tomsk State University, the design methodology of thinking is implemented as part of the educational practice of bachelors of management and is aimed at creating 
entrepreneurial thinking and testing the design thinking method in project activities. A feature of the program is not only the scenario of pre-project work within the framework of design thinking, but also the presentation of a real project with the analysis of iterative trajectories during testing of innovative services. And also the inclusion of the mandatory section "Design thinking and opportunities for the university", which allows revealing the resources and possibilities of innovative development points for the university, including in the format of socio-economic mapping of the city.

The article [11] emphasizes that the modern education system in Russia in recent years is characterized by significant transformations at all levels: from the preschool system to higher education institutions. New generations of standards are being actively developed, special attention is paid to the technological component of education, the vector of which is directed towards the individualization of the educational process, as well as the formation of learners' ability to learn as the most important human competence of the future.

The perception of experimental methods in education is skeptical, despite the fact that they have definitely gained popularity [8]. So, at the conference "Research on Innovation in Education", held as part of EdCrunch, the most interesting of them were presented: design thinking, lateral thinking, CRAFT communication methodology. Schools using the design approach and other creative techniques such as HyperIsland (Sweden), ICRA, and Wonderfull British School of Design can also be called useful in terms of training IT specialists. Technology companies, INTEL, Microsoft and others, pay great attention to methods of creating creative ideas. In management technologies, new mechanics have appeared that have replaced the trend of collaboration: gamification is actively being introduced, based on the transformation of real daily actions in the work of staff into a game process.

The article [12] considers design thinking as a means of developing students' creative potential. The authors examine the phased use of design thinking as part of the lesson. The authors of the article give an example of testing the design thinking methodology in English lessons, while studying the topic "Future" through the concept of change: the lessons discussed various changes that will occur in the future, students touched on various aspects of life, such as the appearance of people, proper nutrition, economy, environment, but a more lively discussion was caused by the topic of how cities will change in the future. It was decided to consider this problem through 6 design steps of thinking. Students were not placed in the framework of what they should consider: the political system, the environment, or the appearance of cities. Each group chose its own line of work, and the teacher served as a facilitator.

As a result of the study, the authors determined: the formed culture, the design of thinking of participants in design sessions: the skills of research, analysis, synthesis, mastering the technique of interviewing, which allowed students to demonstrate their individuality and creativity in a single team.

The experience of using elements of the design thinking methodology in organizing the design work of students of the Russian University of Economics G.V. Plekhanova is presented in an article by Maximova and Pulyavina [13]. The result of the study, they believe that the use of design thinking methodology in the organization of students 'project work allows you to coordinate, direct, adjust students' work at each stage of development of their group project. Thanks to design thinking tools, students learn to deeply research the problem through observation, interviewing, can create a detailed portrait of the user - their end user, learn and describe in detail their characteristics, needs, problems. Correlating this with the existing experience of solutions and limitations, to form a clear vision of the problem situation. All this contributes to the formation of students' valuable communication skills, enterprise, obtained in the process of solving real problems from the external environment.

Of particular interest is the experience of Moscow State Pedagogical University in the use of design thinking technology as a means of psychological and pedagogical support of educational practice of students studying in the direction of teacher education [12]. The authors identify the parameters of technology design thinking: creative approach; teamwork; people orientation; curiosity and optimism.

The most necessary in professional teaching and contributing to the formation of such necessary professional competencies as: the ability to work in a team, tolerantly perceive social, cultural and personal differences; the ability to carry out training, education and development, taking into account social, age, psychophysical and individual characteristics, including the special educational needs of students; readiness for psychological and pedagogical support of the educational process; the ability to organize students 'cooperation, maintain activity and initiative, students' independence, develop their creative abilities; the ability to design the trajectories of their professional growth and personal development; willingness to use systematic theoretical and practical knowledge to formulate and solve research problems in the field of education; the ability to manage the educational and research activities of students, etc.

Using the design of thinking as a means of psychological and pedagogical support of students' educational practice, firstly, it allows you to create socio-psychological and pedagogical conditions for the successful learning and development of each student in the educational environment, namely, it takes into account the individual characteristics of students and helps to build their individual trajectory educational activities.

The result of this study was a program of psychological and pedagogical support for the educational practice of bachelors studying in the direction of "Pedagogical education" using design thinking technology, the value of which is to compare the stages of design thinking with content according to G. Simon, the objectives of the educational practice of bachelors and organizational forms of psychological and pedagogical escorts.

\section{DISCUSSION}

The considered and analyzed practice of introducing design thinking into the system of school and university education, corporate education, and continuing education programs allows us to draw conclusions about the effectiveness of this technology, but it also raises new questions about the content of education and the scientific validity of this methodology in the training process for the 
digital economy. Also, this methodology identifies the necessary revision of the content of programs, pedagogical goals and methods in the system of additional education of children on the basis of quantoriums, technology parks, art parks, etc., and a review in the context of methodology of design thinking of the relevance of art subjects (music lessons, visual arts) in general education schools - the main resources for the development of creative thinking in children.

The introduction of design thinking technology into social innovation will reduce the generation gap between people through a "reset" of the communication culture, a specially organized format for visualizing the creation and translation of society's values. Of course, such a "reset" is impossible without changing the very thinking of a person in the digital world.

The principle "School of Thinking - an Enlightened Nation", formulated in 1997 by Prime Minister Guo Chok Tong, helped to shape the vision of the success of the education system, which was expressed in lifelong learning and focused innovations, which allow to effectively determine priorities and long-term approaches, regardless of the change of government and the passage of time [2].

\section{CONCLUSION}

In 2017, the UK Open University experts identified 10 existing innovations that in the coming years will have the most significant impact on education in the world. One of such innovations is the technology of design thinking, which is an effective technology for the formation of creative thinking and is undoubtedly one of the most advanced technologies in training aimed at creating innovative products and services in the digital economy.

The examples of introducing the design of thinking as a technology of creative thinking in various areas of society and the economy presented in the article make it possible to draw a conclusion not only about its universality, but also about its effectiveness in solving social, economic, and personal problems from the perspective of "human orientation," and with the effects of collective insight at a synergistic level.

Confirmation of the above is the introduction of the design thinking methodology in the management system at the state level, such as, for example, the management of the educational system in Singapore, Korea, Vietnam, in multinational companies, as well as at the level of creation and implementation of educational programs aimed at training specialists with developed creative thinking and focused on creating innovative products, including digital.

\section{REFERENCES}

[1] The Future of Jobs, Report 2018, World Economic Forum, Centre for the New Economy and Society, 2018.
[2] E. Gaible, "Tsifrovaya transformatsiya shkol'nogo obrazovaniya. Mezhdunarodnyy opyt, trendy, global'nyye rekomendatsii," Digital transformation of school education. International experience, trends, global recommendations, Moscow: NIU VSHE, 2019 (in Russian).

[3] T. Kelley and D. Kelley, "Kreativnaya uverennost'. Kak vysvobodit' i realizovat' svoi tvorcheskiye sily," Creative Confidence. Unleashing the Creative Potential Within Us All, Moscow, Azbuka-Atticus, 2015 (in Russian).

[4] E. V. Vasilyeva, "Tekhniki dizayn-myshleniya dlya razvitiya komandnykh navykov i kreativnykh sposobnostey tekhnologicheskikh predprinimateley", Sovremennyye informatsionnyye tekhnologii i IT-obrazovaniye ["Design Thinking Techniques for the Development of Team Skills and Creative Abilities of Technological Entrepreneurs", Modern Information Technologies and IT Education]. Publishing House: Fond sodeystviya razvitiyu internet- media, IT-obrazovaniya, chelovecheskogo potentsiala "Liga internet-media" [Fund for Promotion of Internet Media, IT Education, Human Potential "Internet Media League"], vol. 1, no. 11, 2015, pp. 557-561 (in Russian).

[5] N. Zhuravleva and I. Kuteneva, "Dizayn-myshleniye: dumayem ponovomu: uchebnoye posobiye, [Design thinking: thinking in a new way: study guide]," Moscow: Korporativnyy universitet Sberbanka, [Sberbank Corporate University], 2013 (in Russian).

[6] A. A. Gusakov, "Formirovaniye navykov dizayn myshleniya u menedzherov $\mathrm{v}$ usloviyakh chetvertoy promyshlennoy revolyutsii", ["Formation of design thinking skills among managers in the conditions of the fourth industrial revolution"], Izv. Sarat. un-ta. Nov. ser, Ser. Ekonomika. Upravleniye. Pravo, t. 19, vol. 2, 2019, pp. 147-154 (in Russian).

[7] H. Plattner, Ch. Meinel, and L.Leifer, "Design Thinking Research. Making Design Thinking Foundational," Springer International Publishing Switzerland, 2016.

[8] N. F.Altukhova and E. V.Vasilieva, "Praktika primeneniya tekhnik dizayn-myshleniya v kurse "Internet-predprinimatel'stvo": ot sozdaniya idei do prototipirovaniya", ["The practice of using design thinking techniques in the "Online-entrepreneurship" training course: from an idea to prototyping"], Vestnik finansovogo universiteta [Bulletin of the Financial University], t. 31, no. 3, 2017, pp. 194-200 (in Russian).

[9] K. Robinson, Shkola budushchego. Kak vyrastit' talantlivogo rebenka, [School of the future. How to raise a talented child], Moscow: Mann, Ivanov i Ferber, 2016 (in Russian).

[10] T. Braun, Dizayn-myshleniye: ot razrabotki novykh produktov do proyektirovaniya biznes-modeley, From New Product Development to Designing Business Models, Moscow: Izd-vo Mann, Ivanov i Ferber, 2012 (in Russian).

[11] N. Galoy and I. Gorbenko, "Tekhnologiya dizayn myshleniya kak sredstvo psikhologo-pedagogicheskogo soprovozhdeniya uchebnoy praktiki studentov, obuchayushchikhsya po napravleniyu "Pedagogicheskoye obrazovaniye"," Problemy sovremennogo obrazovaniya, [Problems of modern education], no. 6, 2018, pp. 3542 (in Russian).

[12] A. Krotova and A. Barkova, "Dizayn myshlenie kak sredstvo razvitiya kreativnosti uchashchikhsya", [Design thinking as a means of developing creativity of students], International scientific review, no. 4, 2016, pp. 195-197 (in Russian).

[13] S. Maksimova and N. Pulyavina, "Dizayn-myshleniye v organizatsii proyektnoy raboty studentov", [Design thinking in the organization of design work of students], Rossiyskoye predprinimatel'stvo, [Russian Entrepreneurship], t. 19, no. 4, 2018, pp. 1323-1330 (in Russian). 